\title{
BUILDING STUDENTS' CHARACTER THROUGH FAIRY-TALE TEXTBOOKS
}

\author{
Aida Azizah \\ Teacher Training and Educational Program of Islamic \\ University of Sultan Agung; \\ A Doctoral Student of Indonesian Language Education \\ at Sebelas Maret University \\ Indonesia \\ aidaazizah@unissula.ac.id
}

\author{
Joko Nurkamto \\ A Lecturer of Sebelas Maret University \\ jokonurkamto@gmail.com \\ Sarwiji Suwandi \\ A Lecturer of Sebelas Maret University \\ sarwijiswan@staff.uns.ac.id \\ Muhammad Rohmadi \\ A Lecturer of Sebelas Maret University \\ rohmadi_dbe@yahoo.com
}

\begin{abstract}
Indonesian language teaching has been developed based on character-building approach. One effort that can be done to develop and teach values of character education towards students is through fairy-tale textbooks. Fairy-tale is one of literary works which is not only for reading as entertaining media, but also for building characters and influencing the readers. Therefore, the contents of the fairy-tale should perform moral values that are good for the students' character development. The ideal expectation of the fairy-tale reading activity is that the students can identify types of characters and apply them into their daily lives so that they will shape a good personality. Character-building values integrated in fairy-tale textbooks are stated in the material contents and teaching-learning activities. The contents of fairy-tale textbooks can be one of the modelling types of character value implementation in students' personality. In the teaching and learning process as the developing digital era, the students are taught to behave well. However, in the real implementation, fairy-tales as the media of students' character-building, are decreasing as the existence of online games. It shows that the students' perspective to leave literary works becomes higher in the daily life. On the other side, the existence and quality of fairy-tale textbooks used by Indonesian language teachers are still low and only restricted from the textbooks provided by the government. Related to this, efforts to realize the character-building through fairytale textbooks need to be seriously made since character-building can be implemented in fairy-tale appreciation subject.

Keywords: students, character building, fairy-tale textbooks
\end{abstract}

\section{INTRODUCTION}

Improvement of students' learning achievement is a result of teaching and learning efforts at school carried out by teachers to improve the learning process quality. Curriculum changes also require some changing consequences in the learning paradigm. The changes also need to be done by teachers. One of the learning paradigms as a result of the curriculum changes is the learning orientation which firstly focuses on the teachers then it turns to focus on the learners; the methodology which is firstly expository, then it turns into participatory; further, the used approach which is commonly dominated by textual approach, it turns to be mainly contextual approach (Trianto, 2011:8). Based on the situation, it is essential for the teachers to choose the most appropriate textbooks, which are suitable with both teaching and learning purposes and students' characteristics.

Teaching and learning activities at school need to be supported by qualified textbooks. In the teaching and learning process, textbooks play important and useful roles. Textbooks are important to help student work for the students' role as learners, to give guidance to the teachers as the ones who transfer the knowledge, and to support schools as the education organizers. For students, textbooks can be used as a guidance in the learning process so that they can learn the learning materials from the textbooks used. In this case, textbooks can be as additional and complementary or comparative information sources with another information which has been used by learners.

Fairy-tale appreciation skill is one skill that includes in the basic competence of literary aspects in an Indonesian language subject that must be possessed 
by junior high school students. However, in the reality, in the teaching and learning process conducted by teachers, they give limited and monotonous materials. In conveying the lesson, the teachers do not explore students' potentials and they lack character-building contents, though actually the character-building values through learning is absolutely needed by the students considering that the purpose of education is as stated in the purpose of the national education. It is in line with the previous research that character-building is important in the education curriculum in America. Character-building curriculum and score clarification program are very crucial in economic development and choices for children. By score clarification program, it is expected that each child has good characters suitable with the characters expected in the education curriculum. By good characters had by the children, country and education world will be good, safe, strong, and controlled (Benson, 2010).

The learning process of fairy-tale appreciation through character-building places the importance of speeches in predicting characters or personalities of the speakers. It means that speeches produced by children can show the children's personalities, including either children in the elementary level or students in the secondary level. The ideal expectation is that the children can have good characters and personalities. Related to this, how to build characters and personalities of the children should be taught since they are young. The efforts to teach children good characters and personalities are made based on a result of the previous research about the use of literary work by children in their learning process. From this, it is known that the learning process through fairy-tales conducted for years can influence the readers' responses in facing the daily routines, example: social life in the communities and societies. In the research, it focuses on the recommendation that folklore should be used as materials in character-building learning process for students (Bryan, 2005).

Good textbook materials can be used as model alternatives of the learning process which apply character-building for each self, each student, each teacher, and each society. In this research, it is designed to describe the efforts to realize characterbuilding values through fairy-tale textbooks. In this case, the character-building is implemented by fairytale appreciation learning process.

\section{RESEARCH METHOD}

This research used descriptive and qualitative method. The qualitative research was used to get a description about efforts in realizing character-building values through fairy-tale textbooks.

\section{DISCUSSION \\ 3.1 The Character- Building Implementation at School}

Each school has each duty. The important duty from each school is not only to realize and increase the mastery of information technology for the students, but also to have responsibility for the students, one of which is to make the students an individual with a good, decisive, and wise personality, in the daily life. In this case, an education philosopher, Dewey, stated that education has main purposes as the activator of educational efficiency, as the former of human wisdom in citizenship, and as the creator of men with character, that it can be said that education is accordingly not only to fulfil one circle's needs (Jihad et al 2010: 61).

The implementation of character-building values can be done in an integrated way through some activities, namely learning processes which can be done either in the classroom or outside classroom, management at school, and also some activities related to students' coaching. The implementation of the learning process can be applied through integrated character-building, that is an education system which introduces character-building values, understands the importance of character values, knows how to internalize character values which are applied in the daily life. The character-building learning process is obtained through some learning processes in all subjects.

The implementation of character-building values in the school management activities is organized by planning sector, executive sector, and control sector. Components of character-building values that will be planned, executed, and controlled are: (1) character values of standard of competence assessment, (2) curriculum contents of character values, (3) character values in the learning process, (4) character values of the teachers and educational officers, and (5) character values of students' coaching. Meanwhile, the implementation of character values in the students' coaching activities is by the development of potential of each student, talent of each student, interest of the students, and a character of independence and happiness of the students which are helpful for themselves, families, and the surrounding communities (Kemendiknas, 2011: 26).

Barnawi (2012: 67) explained that there are four models of implementation methods of character building values which are applied at schools, namely: (1) autonomy model is a model which places characterbuilding values as the subject itself; (2) integration model is a model which unites values and characters which are shaped and applied in each subject; (3) extracurricular model which can be done by giving some additional activities outside the learning process orienting to give coaching to the students; (4) collaboration model is a model which can be applied by doing a collaboration or combination among 
autonomy model, integration model, and extracurricular in the whole school activities.

Meanwhile, Mustakim (2011, 91:105) described that character-building approach which can be implemented in every school can be performed through three approaches, namely (1) formal education approach, (2) school-culture educational approach, and (3) paradigmatic educational approach. Formal approach is done by including character-building education in the education curriculum. School-culture educational approach is character-building management which is done and developed by implementing culture management at school. Character-building education through paradigmatic approach is a paradigm change in the main education components which directly relates to students' character-building.

Based on the definitions, value points, and character-building implementation mentioned before, it can be concluded that character-building education is a type of education system which is aimed to help educators build the students to have noble characters through various types of actions, such as behaviour, speeches, attitude, performance, and some other types which are related to things consciously done by the teachers which can influence students' characters. Points of character-building values are implemented at school through some actions and facilities which are aimed to grow character values of the students so that they become students with noble characteristics.

Character-building education is applied in all subjects at school which have purposes to improve the quality of education implementation at school and the achievement of the students' result as a complete, integrated, and balanced way which are directed to character-building achievement and noble attitude suited with standards for the education competence. It is expected that every student can develop and apply his or her knowledge he/she acquires, learns and internalizes character-building values and noble characters so as to realize them in the daily lives.

\subsection{Character-Building Integration in Fairy-tale Appreciation Learning Process}

Character-building integration according to Hidayatullah (2010: 56) is (1) describing basic competence in each subject, (2) identifying aspects or character-building materials which will be integrated in the subjects, (3) integrating character-building values into the basic competence which is considered to be relevant and suitable, (4) implementing the learning process, (5) determining the learning method, (6) determining the learning evaluation, (7) determining the learning sources. One of the efforts in characterbuilding integration to develop and instill characterbuilding values for the students is by optimizing the learning processes of fairy-tale appreciation of which the material is stated in the contents of the learning materials and learning activities. The material contents of fairy-tale appreciation are set and arranged in such ways that make them suitable with the needs of the students and teachers based on the character-building values. The Ministry of National Education has formulated 18 character values that will be instilled in the students' performance as one way to establish the nation characters, namely: (1) religious, (2) honest, (3) tolerant, (4) disciplined, (5) hard-working, (6) creative, (7) independent, (8) democratic, (9) curious, (10) nationalistic, (11) love the country, (12) being respectful of achievement, (13) communicative: love to socialize or proactive, (14) love peace, (15) love to read, (16) caring for social environment, (17) aware of social matters, (18) responsible.

The aforementioned characters are expressed in the illustrations, themes, examples, pictures, exercises, and media of learning activities of the students. Character-building values will be conveyed implicitly, but they are relevant with the students. With this effort, the values will be easily applied in the students' daily activities. This is conducted to motivate the students to really apply those character values in the real life. Therefore, the students are expected to instill the character values in their spirit, not only when they are at school or while they are in the learning activities. Thus, there should be a collaboration among teachers, students, schools, families and environments in the process of building the students' characters so that it will give the maximal result.

\section{CONCLUSION}

The Indonesian language learning process is developed suited with the character building. In this case, it needs efforts to realize students' characters by developing, instilling, and optimizing fairy-tale appreciation learning process. Character-building values which are integrated in the learning process of fairy-tale appreciation are conveyed through the presentation of material contents and learning activities at schools using fairy-tale textbooks.

\section{REFERENCES}

Benson and T.S Engemen. 2010. "Journal of Moral Education". Internasional Journal. Vol.4 no.1hal 53-59.

Borg, Walter R and Meredith Damien Gal. 1983. "Educational Research: introduction". Boston: earson Ltd.

Hidayatullah, Furqon. 2010. "Pendidikan Karakter”. Surakarta: Yuma Pustaka.

Kementerian Pendidikan Nasional. 2013. "Strategi Pemebelajaran Pendidikan Karakter". Bandung: Remaja Rosdakarya. Hal 8-9.

Tomlison, Bryan (ed). 2012. "Material Development in Language Teaching. Cambridge". Cambridege University.

Trianto. 2007. "Model-Model Pembelajaran Inovatif Berorientasi Konstruktivistik". Jakarta: Prestasi Pustaka Publisher. 